\title{
Social Management in China in the 21st Century: Trouble and Breakthrough Based on the Different Management Subject
}

\author{
Wang $\operatorname{Bin}^{1} \&$ Huang Lei ${ }^{1}$ \\ ${ }^{1}$ School of Political Science and Public Management, Southwest University, Chongqing, China \\ Correspondence: Wang Bin, School of Political Science and Public Management, Southwest University, \\ Chongqing, China. Tel: 86-1-399-600-2482. E-mail: swu_pm@163.com
}

Received: April 27, 2013 Accepted: May 2, 2013 Online Published: September 29, 2013

doi:10.5539/par.v2n2p73 URL: http://dx.doi.org/10.5539/par.v2n2p73

\begin{abstract}
In China, there is a social management mode plight because of asymmetric information status which is based on the opposition concept between the government and society, and the public in the rapid development and changing era. In order to solve the problem of social management, it is necessary to make the government and non-governmental organizations scientific division of duties, solve NGO legitimacy issues, reform the way of the fund-raising, clear legislative mode, as well as strengthen the various non-governmental organizations to participate in social management and other ways to make the non-governmental organizations truly assume the responsibility of social management.
\end{abstract}

Keyword: NGO, social management, pathway

Currently, China's social development is being social transformation of market-oriented and democratic reforming. In the process, we need the government departments, non-governmental organizations and other main body in the social management make a variety of targeted management on the different areas of the social system, in order to achieve the harmonious development of society. But, there is a necessary link between the problems which exist in the current reality of the social development in China and the existing social management mode. Therefore, under the premise of recognizing the two administrative body of government departments and non-governmental organization's duties in different areas of social management, we focus on the plight of China's non-governmental organizations involving in the social management and the main way of solving the problems.

\section{The Connotation and Research Status of Social Management in China}

In China, social management formed in the early 1980s as a relatively independent concept. More experts and scholars defined the basic connotation of social management from the angle of sociology and public management, basically has the following several kinds of representative opinions: Li Chengwei considered that, in a broad sense, social management referred the government and non-governmental public organization manage all kinds of social and public affairs (including political, economy, culture, and society), which in fact was same as public management known to most people. In a narrow sense, as opposed to a political management, economic management in general, it referred to the transaction management and governance to the social public affairs tossed off political control and economic management ones. Zheng Hangsheng suggested social management was a process that government and social organizations organize, coordinate, serve, supervise and control the elements of social system and areas of social life and connections of social development in order to promote social system coordination. Yu Keping regarded that the concept of social management can be defined as government by making a special, system of policies and regulations, manage and standard the social organization, cultivate the reasonable structure of modern society, adjust relationship of social interest, in response to social demands, resolve social contradictions, maintain social justice, social order and social stability, create a reason, tolerance, harmonious and civilized social atmosphere and establish the coordinated development of economic, social and natural social environment. From what has been discussed above, this paper deems that social management refers to the process which the government-led social management, including other social organizations and the public, subject to promote social system coordination, achieve the established social development, by various means organization, coordination, service, supervision and control on the part of the social system, different fields of social life and each links of social development 


\section{Judging the Core Problem of the Current Chinese Society's Development}

China's social development is facing the declining and missing of the public power sector credibility in the social field, it's needless to avoid the phenomenon, but it's more important to judge what is the root cause of the existence. Analyze why there is such a distrust mentality or state between the government and society, public? We argue that the core issue of the whole society's development is: in the macro context of the lack of modern Chinese culture, there is a social dilemma between government and society and the public based on the concept contradictory information asymmetry state.

Based on the concept of opposition is a origin factor of the problem. It's said that there is a different understanding about who is the social management body, between the public power sector, as well as its leaders and managers, and society as well as among the public. Chinese political tradition is the government and managers priori think that the community and the public, especially people, do not have the capacity and quality to manage the state and social. Leaders and managers must have to back them manage.

In terms of society and the people, there is also mental of sitting pontificating or depending on others. So-called sitting pontificating is said the social groups who have a wealth of social resources, social capital, have the ability of formating and leading the social organization, they very clearly know the problems existing in the current social management and social organizations, they also expound their dissatisfaction and hope to the reality in certainly occasions, but the social cost is too high and can not go to practice, and therefore they can only sit pontificating. And the mental of depending on others is saying those civic who have a sense of social responsibility and dissatisfaction with the reality of social organization status, they do not have the resources and capacity to change the reality or to create their own new, can only but expect others to change.

Therefore, we can see that the government thinks the masses are being regulated from two perspectives. On the one hand, if the masses do not be taken control, they will oppose them even rebell, which is the inertia of thinking of the ancient Chinese feudal regime. On the other hand, the government does not believe the masses have the ability of self-management and to participate in social management, and they need the government to control. When the government in full controlling all areas of society, due to the limitations of its human resources, financial resources, material resources, and so on, it is impossible to fully meet all the needs of the masses of the public service, and even some done a poor job, or even cause opposition of the masses. And a part of the masses with a certain level of education and higher level, have the analysis capabilities of these issues, they can find out the mistakes of the government, but because of the "sit pontificating" or "psychological of depending on others", they also can not change the reality, they can only do is to evaluate, interpret and disseminate, and finally causing distrust between the masses and the government.

The reason of establishment of the government is that social citizen as an individual are unable to carry out the effective allocation of social resources and the production of various public goods, it's necessary to transfer their rights and entrust the government to manage. The government should take a variety of services to meet the public's demand for public services as response. But once the government established, the public have lost their respective powers, and the government as a entrusted manager have a lot of resources and rights to dispose. This contract is unlike commercial contract, but a intangible contract based on the philosophy and recognition psychology.

The sense of mistrust manifested by this contract is a very dangerous performance, it must be subject to the attention of the government, and this distrust is closely related to information asymmetry, there is a causal relationship between each. That is, the contract failure was caused due to information asymmetry, but contract failures further deepen the degree of information asymmetry.

On the basis of this origin factors, information asymmetry is the institutional factors of problems. A direct manifestation of the existing information asymmetry is the lack of effective mechanisms of cooperation between the government, social organizations and the public, due to the gap between society and government, but also due to the government-led social management.

\section{The Formation of China's Current Social Management Mode and the Plight of Profiling}

The plight of social management based on asymmetric information status due to the concept of opposition, is due to the accumulation of "government control - to absorb social organizations assisted - social organization coordination" social management model. The level of this model in the actual operation appears various paradoxes and dilemmas on management, especially in the environment when most of China's legal and social organizations that have the resources, authority and legal status are founded and led by the Government. 


\subsection{The Evolution of Social Management Mode}

Due to the paradox of asymmetric information and distrust, China's social management is led and control by the government, as well as various social organizations involving in assisting. Actually, most legitimate social organizations in China are just government-affiliated institutions which completely controlled and manipulated by government. Some social groups have purely become government intelligence departments or institutions, and the person in charge of a society is directly appointed by the government to accept the leadership of the government.

Phase I: Government control. Government control is first reflected in the implementation of the non-governmental organization affiliated management system. Societies Registration Ordinance requires, all social groups must find a regulatory government department before registration, they can be registered to the civil affairs department only getting the approval documents of the government departments. It is obvious the means of control of a government to non-governmental organizations, And requirements for the unit in charge of the selection is very strict, so we can imagine the difficulty for social groups with no background. Therefore, we can see that, virtually, all Chinese public organizations, social organizations, associations guild that can legally acquire the status are effectively controlled by government in order to set up and run. This has artificially developed barrier to the development of public welfare which is pure or has no government background.

In fact, the formation of this phase is based on the idea: a product of the State and Society in the zero-sum game mentality, this philosophy cause a way of thinking that "civil society, non-governmental organizations, is the nation's hostile", such a anatural antagonistic relationship. It is said that the country is afraid of NGO becoming the opposite side of the country, and therefore want to take the anchored system controlling rules.

Phase II: system to absorb. It is one way or the process that the system of government absorb the social elite and their representing political forces, social forces by various forms, give the legal status to its various activities, while reduce management conflict and unify the opinion. System-absorb is a starting point of system-absorb. This is the same as that there is always two systems in the national governance and social management in traditional Chinese feudal society. Centralization built by monarch ethics is the national governance system, centralization built by kinship geopolitical and other social relations is the social management system, but in fact the social management system is always also belong to the macro system of national governance, namely the three cardinal guides and the five permanent members of the five cardinal fundamental law. In that era of history, social managers as the representative of the patriarch local gentrification achieve the social management outside Bureaucracy as the basic point of maintaining the Confucian fundament. It docks with the state system, and is responsible for the transport and transmission between the state and society, and then it achieves the buffer and integration functions of the state and society.

After is to implement policies-absorb, and make the social elite involve in the field of public power. At present, China's main way of administratively absorbing the social elite is against the elite of the new economic organizations in the two new organizations, on the one hand, absorb them through the formal system, establish social organization led by the party committee and government within the economic sphere of various institution, in order to publish information platform for them to maintain their own interests.

The final step is the system-absorb's expansion and steering, when the government found that the absorption of the elite will exacerbate social division and fault, considering factors such as political stability, social management occurs some changes, vigorously strengthen extending of absorbed objects, began to absorb and accept the general public and the grassroots, and began to focus on social issues.

Phase III: collaborative governance. The reason why it developed to the stage of cooperative governance is that when the social develops to a certain stage, as the government, they can not handle harmony of governance and social management even through institutional absorbing, which means that when the government found that invalid government management and governance predicament exist in some social fields, they will be forced to make a choice of collaborative governance. This choice means that the government recognize and approve that social organizations and social organizations in the field of social management have a collaborative management position.

\subsection{Profiling of the Current Dilemma of Social Management Mode in China}

When the management and governance of our society developed to the stage of collaborative governance, it can indeed achieve the effective running of the social management to some extent. However, in-depth analysis, this model still exist some problems, and with the development of society, the problem is likely to be a plight which is difficult to get rid.

First, collaborative governance, in fact, is based on the government's political control and institutional absorbing 
basis, and will continue to cause self-organizing capacity of the social decline and social self-management capabilities shrinking. In other words, the government should serve as a guide and coordinator of the non-governmental organizations in social management, rather than absorber. When the government unconsciously become the contractor and controller of social organizations in the process of absorbing and controlling, once this case, the event will lead to descent of the self-organization ability of society. When the government behavior in the social management is unlimited expanding, the government is constantly involved in the handling the social conflicts, the state and society become the same individual without boundaries, then the first is to obliterate the duality of the state and society, it cause society's dependence to the state, and also cause the demise of the social organizations in the social management. For example, after Qantas strike in November 2011, the federal government involved in the activity, Qantas unions expressed their regret for this behavior, and worried that the federal government would violate and control the right of unions to collective negotiation. In addition, the strength behavior of the government in the field of social management will bring national penetration of the social spirit field, resulting in the decline of judgment and affordability of the social members on the future expectations, and a rise of the uncertainty of the future. Again, the Government having a strong behavior will cause a lot of difficulties and problems, it is because that once the social problems appear, the Government has a leadership position in the breadth and depth, they will naturally become the target of public criticism of the public, and it will be more difficult to achieve their original purpose, but resulting in the reduction of the government's credibility.

Secondly, it will cause the power of the government unbounded expansion and squeeze social organization. We know that any kind of power, especially political power have the natural expansion inertia, it did not have consciously space and boundaries of self-definition, if no boundaries, it will be extending the expansion, when the expansion rises a certain stage, the so-called social organizations collaborative position will no longer exist, or directly convert into a government dependent organization.

\section{Vigorously Developing the NGO is the important way to solve the dilemma of social Management}

Based on the above discussion and analysis, the paper argues that to break the plight of China's current social management mode, we must ensure that the problem of legitimacy of the NGO, fund raising, legislative mode and perfect type solved, and make the NGO truly assume the responsibility of social management.

\subsection{To Resolve the Legality of the NGO}

The legitimacy of the NGO should be a multi-level structure, including political legitimacy and social legitimacy, administrative legitimacy and legal legitimacy.

First, the political legitimacy is said that whether the NGO inner purpose, intent and mission is compliant with the requirements of the Chinese Communist Party objectives and tasks to China's current development, which is the fundamental premise of our society organizations to exist. At this point, we believe that we can have a correct understanding of China's NGO political legitimacy through the following points of view. First, the Chinese Communist Party leading social organizations, social groups is thought leadership, rather than action leadership, it clearly points out in the party constitution about social organization, "the party's leadership is mainly political, ideological and organizational leadership, the party must ensure that people's organizations actively, independently and responsibly, work in concert. " Second, the fundamental purpose of the Communist Party of China in the field of social is that: "to improve people's livelihood is the focus, the people most concerned about, the most direct and most practical interests, efforts to form a situation in which all people do their best, and live in harmony". This precisely point out the non-governmental organizations in the field of social management is practicing the mission and tasks of the party constitution. Combining these two reasons, the paper argues that these two programmatic provisions in the party constitution express this kind of a meaning: under the leadership of the party's political stance, ideological guidelines, and various non-governmental organizations to the should concretely practice the party constitution proposed task of "all people do their best, and live in harmony". In other words, the party demonstrates the direction, assign tasks, and NGO independently, self-specific implement and complete. So where does the political legitimacy of the NGO certifications come from? We argue that the government should think about more authoritative certification department during the further reform.

The next is administrative legitimacy. This administrative legitimacy is understood from a management perspective, it refers to the legitimacy of the organizational form of the NGO's organizational architecture. Namely: non-governmental organizations should have a complete scientific organizational structure, working procedures and organizational norms and organizations operating mechanism. So far, administrative legitimacy certification comes from the certification of civil affairs department, but this paper argues that because of the negligence problems arising from the certified staff of the civil affairs departments who were faced with a large number of certification, and the problems caused by the certified staff's lack of management expertise and quality, 
certification of NGO administrative legitimacy should reform to the specialized agencies certification that have management professional knowledge and skills, and they should present the whole NGO administrative mechanisms report to the registration department, registration department recognize and provide certification.

Again is the social legitimacy. Social legitimacy is the fundament that non-governmental organizations live in our community, and achieve the public recognition, it refers to the legality of a civil norms in line with cultural traditions and social habits, it is recognition of social and civic to the community, and it is the basis of its presence and activities, therefore its certification comes from the public.

The last is the legal legitimacy. It comes from meeting the legal and institutional rules. Due to the dual leadership of the current registration system and the non-competitive principle restrictions, it severely affected the Chinese NGO survival legal environment. Therefore, to improve the relevant laws and regulations of the NGO as soon as possible is problem to be solved, while Shenzhen has made a huge exploration.

\subsection{Reform NGO Financing Problems}

NGO want to normal operation, on the basis of legitimacy, but also solve the problem of funding, or otherwise unable to survive. For now, in addition to the small amount of money from the civil (including personal and corporate), funding of government is the main source, including: commissioned project funding, government policy funding, funding and incentives of the government-run fund.

The commissioned project funding is that the government purchase of a particular public service, and fund to specific social organization. However, non-governmental organizations and social organizations are difficult to obtain this type of funding in China. In fact, this is a good development of ways and means, but there is still some idea of the obstacles in our government, or no specific plan, with randomness.

Policy funding is funding to the social organization from time to time according to policy priorities in order to achieve a specific public policy objective. Another is from the government-run fund, last is local incentives.

We argue that on the basis of a wide range of funds sources of China's non-governmental organizations and social organizations, namely: a variety of ways and measures of fighting social individuals, enterprises more donors, it should mainly take government funds investment. But another question raises, government invest fund, whether society organizations will be asked to submit to the management and control of the government. This paper argues that in the existing government subsidies, purchase services should serves as the main channel (because the policy funding does not have a long-term), it clear responsibilities and obligations of both parties through contractual agreement, the government never mind the internal operation of the NGO and the social organization, only accept public service and product in accordance with the contract. Of course, there is a supervision problem in this intermediate.

To do government purchase and injection into non-governmental organizations, we think we should do the following work.

First, develop policies and improve the system. The "Government Procurement Law" implemented in 2003 does not cover society organization's participating in the public services and products procurement, the government should formulate policies related to public services and social organizations to purchase as soon as possible, and improve its operating system.

Second, expand the scale, field and target range of government purchases of public services. For now, either east or west, government purchase of public services and products to the NGO are still small and limited, especially in the dominant public service areas. China's public service purchased is mainly pension, social services, and to undertake some of the functions of government departments, and it is also unusual in public health, education, culture and other leading public services.

Third, develop competitive, openness independent buying patterns. China should be established buying patterns in accordance with a clear public service standard, contract both parties independent as soon as possible, and adhere to the general principles of fair bidding. But in fact, the most public services purchase appears in the patterns of non-independence purchase, or so-called form purchase. That is, the government procurement of services more directly commission affiliated institutions or non-governmental organizations, or government in order to undertake some of the functions of the government itself, they undertake part of their own services and management by the establishment of non-governmental organizations, and give to funds and resources in the form of project, thus forming a formal public service purchased.

\subsection{Reform the NGO Legislation Mode}

NGO take this purely "private" way of civil society, freedom association to solve this "public" problem of supply 
of public goods which is long-term in charge of the government, this way determines that the legal relationships involved in the whole process will inevitably cut across traditional classification of the legal department. Therefore, on the issue of legislative model, special legislation of NGO undoubtedly has a great significance and efficacy to reverse the situation of strong government and weak social. Therefore we think that the NGO legislation model should be adopted such an organic unity, centralized multi-level legislative mode in which Associations Act and non-governmental organizations act as the Basic Law, in line with other individual society laws and administrative regulations or regulations.

\subsection{Improve NGO Participation in Making of Public Policy}

In accordance with the relevant laws and regulations of the State Council, the current NGO in China is divided into four main categories of social organizations, institutions, foundations, and private non-enterprise units. In the four major categories, that which is able to participate in public policy-making process about social management is very limited. Therefore, as the two main social managements, this study suggests that the government must have the courage to break the information asymmetry, and actively build the two main communication mechanism of governmental and non-governmental organizations during the social management, resulting in the NGO's real participating in society management. So that it provides the organizational means by which citizens can orderly participate in public decision-making, supervise and improving government action.

In fact the work has made certain achievements in some non-governmental organizations which develop since the reform and opening up, and played an important role, but mainly in the field of environmental protection.

From another perspective, the NGO exist to meet certain purposes of different groups, then during the process of involving in the formulation of public policy, there must be some non-governmental organizations that have interest endorsements, and the opinions and suggestions are linked with the interests of the social classes in the course of involving in the development. It is easy to produce this behavior that groups with vested interests take it as a carrier to seek benefits. Therefore, it is necessary to expand the type space of NGO, vigorously develop the various non-governmental organizations that make the public interest and social justice as the mission, especially empower the vulnerable groups, and build corresponding NGO.

Currently existing NGO on behalf of vulnerable groups, due to the limitations of the registration regulations, is also in the edge of legality, and service activities is limited to cases activist to enterprises, basically can not participate in the formulation of government and public policy. But some Industry Association has a strong public policy-making influence and participation. The existing of gap in these two tissues is very dangerous. Therefore, the government must establish some related measures that allow various non-governmental organizations on behalf of all social groups to fairly, openly and legitimately participate in public policy making activities, and realize the function of coordinating social disparities and orientating social justice of NGO in social management.

\section{Conclusion}

At present, the concept and mechanism of social management in china are only just starting, and within the efforts of government, social organizations and citizens, reform and innovation of social management in every stage can be run smoothly. From a practical perspective in China, quite a number of social organizations are created by the government, or split off from some organizations of government system. Because of the rapid transformation of society, the relationship of management and being managed has been replaced by cooperation and positive interaction of partnership between government and social organizations. At the same time, more and more citizens are participating in social management, enhancing their subject consciousness and responsibility consciousness. However, social management is facing increasingly challenges, the transformation of government functions and cultivating the social space of freedom as well as maintain the government management ability are the a severe test of social managers.

Because the author's ability is limited, the research on the study of the social management is still shallow, the opinion and the suggestion is not enough comprehensive and mature, study and practice will be summarize and perfect in the future.

\section{References}

Li, C. W. (2005). Chinese public administration. Innovation of social management system-based on the angle of public management.

Zheng, H. S. (2006). To more about governance society: Social construction and social management. China Renmin University Press.

Yu, K. P. (2007). Beijing society proceedings. Eight reasons for reforming and completing the system of social 
management.

Yu, K. P. (2006). Chinese Social Sciences. Chinese civil society: The concept, classification and institutional environment.

Yu, K. P. (2002). The rise of Chinese civil society and governance changes. Beijing: Social Sciences Documentation Publishing House.

Jin, J. H. (2003). Yunnan Social Sciences. Social management in transition: NGO positioning and build mode 5.

\section{Copyrights}

Copyright for this article is retained by the author(s), with first publication rights granted to the journal.

This is an open-access article distributed under the terms and conditions of the Creative Commons Attribution license (http://creativecommons.org/licenses/by/3.0/). 